\title{
Pathophysiological consequences of receptor mistraffic: tales from the platelet $\mathrm{P}_{2} \mathrm{Y}_{12}$ receptor
}

Margaret R Cunningham ${ }^{1}$, Riyaad Aungraheeta ${ }^{2}$ and Stuart J.Mundell ${ }^{2}$

1 Strathclyde Institute for Pharmacy and Biomedical Sciences (SIPBS), University of Strathclyde, Glasgow, UK

${ }^{2}$ School of Physiology, Pharmacology and Neuroscience, Faculty of Biomedical Sciences, University of Bristol, Bristol, UK

Correspondence: Stuart Mundell, School of Physiology, Pharmacology and Neuroscience, Faculty of Biomedical Sciences, University of Bristol, Bristol BS8 1TD, UK; email: s.j.mundell@bristol.ac.uk; Tel +44 (0) 1173311440

\section{$\underline{\text { Abbreviations }}$}

Adenosine diphosphate (ADP); centronuclear myopathy (CNM); Charcot-Marie- Tooth (CMT); constitutively active mutants (CAMs); Genotyping and Phenotyping of Platelets consortium (GAPP); G protein-coupled receptor (GPCR); G protein-coupled receptor kinase (GRK); gonadotropin-releasing hormone receptors (GnRH); intracellular loop (ICL); loss-offunction (LOF); Na+/H+ exchanger regulatory factor (NHERF); postsynaptic density 95/disc large/zonula occludens-1 (PDZ); proteinase-activated receptor (PAR); regulators G protein signalling (RGS); single-nucleotide polymorphisms (SNPs); sorting nexin 27 (SNX27); transGolgi network (TGN); transmembrane helix (TM). 


\section{Abstract}

Genetic variations in G protein-coupled receptor (GPCR) genes can disrupt receptor function in a wide variety of human genetic diseases, including platelet bleeding disorders. Platelets are critical for haemostasis with inappropriate platelet activation leading to the development of arterial thrombosis, which can result in heart attack and stroke whilst decreased platelet activity is associated with an increased risk of bleeding. GPCRs expressed on the surface of platelets play key roles in regulating platelet activity and therefore function. Receptors include purinergic receptors $\left(\mathrm{P}_{2} \mathrm{Y}_{1}\right.$ and $\left.\mathrm{P} 2 \mathrm{Y}_{12}\right)$, proteinase-activated receptor (PAR1 and PAR4) and thromboxane receptors (TP $\alpha$ ), among others. Pharmacological blockade of these receptors forms a powerful therapeutic tool in the treatment and prevention of arterial thrombosis. With the advance of genomic technologies, there has been a substantial increase in the identification of naturally occurring rare and common GPCR variants. These variants include single-nucleotide polymorphisms (SNPs) and insertion or deletions that have the potential to alter GPCR expression or function. A number of defects in platelet GPCRs that disrupt receptor function have now been characterized in patients with mild bleeding disorders. This review will focus on rare, function-disrupting variants of platelet GPCRs with particular emphasis upon mutations in the $\mathrm{P}_{2} \mathrm{Y}_{12}$ receptor gene that affect receptor traffic to modulate platelet function. Further this review will outline how the identification and characterization of function-disrupting GPCR mutations provides an essential link in translating our detailed understanding of receptor traffic and function in cell line studies into relevant human biological systems. 


\section{Introduction}

Blood platelets play a critical role in the cessation of bleeding upon vascular injury. However, they also contribute to the low-grade inflammation that drives endothelial dysfunction and the formation of occlusive thrombi upon atherosclerotic plaque rupture (1). Under physiological conditions the continual release of inhibitory prostaglandins and nitric oxide by the endothelium prevents platelet activation and adherence to the vessel wall (2). Upon vessel wall damage, platelets bind to exposed collagen, become activated and release a number of stimulatory mediators including adenosine diphosphate (ADP) which feedback in an autocrine manner (3). The subsequent release of soluble platelet agonists promotes platelet aggregation to ensure rapid haemostasis at the site of injury and the formation of a stable clot, preventing further blood loss.

Platelet activation is a tightly regulated process with changes in platelet reactivity significantly impacting upon the haemostatic process. Increased platelet activity, for example at the site of atherosclerotic plaque rupture, may result in myocardial infarction or stroke. Conversely decreased platelet activity is associated with an increased risk of bleeding. Platelet G protein-coupled receptors (GPCRs) are critical regulators of platelet function with pharmacological blockade of these receptors a powerful therapeutic tool in the treatment and prevention of arterial thrombosis (4). In order to optimise the use of existing antiplatelet drugs and to develop new therapies, more detailed knowledge of the molecular mechanisms that regulate GPCR-mediated platelet function is still required.

\section{The platelet $\mathrm{P} 2 \mathrm{Y}_{12}$ receptor - a key player in platelet activation}

Platelet activation is a multistep process consisting of platelet adhesion, shape change, granule secretion and aggregation. It is mediated by a number of cell surface receptors, including integrins and ion channels as well as GPCRs (3). Of the GPCRs present on the platelet surface, the key receptors involved in platelet activation include the protease activated receptor (PAR)1 and PAR4, the purinergic $\mathrm{P} 2 \mathrm{Y}_{1}$ and $\mathrm{P} 2 \mathrm{Y}_{12}$ and the TP- $\alpha$ thromboxane (4). The $\mathrm{P}_{2} \mathrm{Y}_{12}$ receptor plays a pivotal role in platelet activation (reviewed in (1)). Stimulation of $\mathrm{P} 2 \mathrm{Y}_{12}$ receptors by ADP released from the dense granules of activated platelets results in sustained platelet aggregation and secretion (5). In addition, the $\mathrm{P} 2 \mathrm{Y}_{12}$ receptor plays an essential role in potentiating platelet responses initiated by other important 
platelet activators such as thrombin and thromboxane(6). Pharmacological blockade of the $\mathrm{P}_{2} \mathrm{Y}_{12}$ receptor is a powerful antiplatelet strategy in the treatment and prevention of arterial thrombosis associated with coronary atherosclerosis. Clopidogrel, prasugrel and ticagrelor are potent inhibitors of the $\mathrm{P}_{2} \mathrm{Y}_{12}$ receptor with efficient antithrombotic activity reducing the rate of thrombotic events in acute coronary syndrome patients (7).

In order to minimize inappropriate platelet recruitment and activation at the site of a growing thrombus, platelet ADP responsiveness is tightly regulated in human platelets (8-12). $\mathrm{P}_{2} \mathrm{Y}_{12}$ receptor responsiveness rapidly desensitizes in human platelets (13). Previous studies in cell lines have identified that G protein-coupled receptor kinase (GRK)2- and GRK6-dependent phosphorylation of the $\mathrm{P}_{2} \mathrm{Y}_{12}$ receptor is required for arrestin association and desensitization (9). Following removal of $\mathrm{ADP}$ there is a rapid resensitization of $\mathrm{P} 2 \mathrm{Y}_{12}$ receptor responsiveness in human platelets (11). In order to resensitize, the $\mathrm{P} 2 \mathrm{Y}_{12}$ receptor internalizes following agonist addition and then recycles back to the cell membrane following removal of ADP (11). The $\mathrm{P}_{2} \mathrm{Y}_{12}$ receptor, similarly to $\mathrm{P}_{2} \mathrm{Y}_{1}$, internalizes via clathrin- and dynaminmediated endocytosis (14). Intriguingly these two purinergic receptors appear to sort into distinct membrane clathrin coated pits, an observation that has been reported for other GPCRs (15). The mechanisms underlying $\mathrm{P}_{2} \mathrm{Y}_{12}$ receptor internalization are complex and, as with receptor desensitization, are mediated in part by GRKs and arrestin $(14,16,17)$. The small GTP-binding protein ARF6 (ADP-ribosylation factor 6) also plays a role in the internalization of $\mathrm{P} 2 \mathrm{Y}_{12}$ receptors in human platelets (16). Activation of $\mathrm{P} 2 \mathrm{Y}_{12}$ receptors stimulates ARF6 activity which in turn regulates Nm23-H1, an nucleoside diphosphate kinase to facilitate dynamin-dependent fission of clathrin-coated vesicles. Following internalization, the $\mathrm{P}_{2} \mathrm{Y}_{12}$ receptor undergoes rab5-dependent trafficking to a sorting compartment from which it is rapidly recycled (18). Rapid recycling of the $\mathrm{P} 2 \mathrm{Y}_{12}$ receptor had previously been described in human platelets although the mechanism at that time was unclear (8). Blockade of receptor internalization or subsequent recycling results in attenuation of receptor resensitization in human platelets (11). Our understanding of this process has been further advanced by the study of patients with rare genetic variations in the platelet $\mathrm{P} 2 \mathrm{Y}_{12}$ receptor.

\section{Rare genetic variations in platelet GPCRs: shining a light into the receptor / structure function relationship in vivo}

Genetic variations in GPCR genes that disrupt receptor function can lead to a wide variety of human genetic diseases (reviewed in (19)and (20). Advances in genomic technologies have 
led to a substantial increase in the identification and characterization of naturally occurring rare and common GPCR variants. Such variants can include single-nucleotide polymorphisms (SNPs) and gene insertions or deletions with the potential to alter GPCR function and expression. In some cases these variants can inactivate receptor proteins, often referred to as loss-of-function (LOF) mutations (21). Heterozygous expression of LOF mutations can in some cases result in a dominant negative phenotype, with expression of the LOF variant impairing the function of the wild type receptor (as reviewed in (22)). In contrast to LOF mutations constitutively active mutants (CAMs) will lead to agonistindependent signalling. Both animal models and in vitro studies have commonly been used to characterize the molecular pathologies that underlie these naturally occurring GPCR mutations with inactive, overactive, or constitutively active receptors identified that result in pathology. Receptor variants may alter receptor expression, basal activity, ligand binding, Gprotein coupling, receptor desensitization and receptor recycling (21). An ever increasing variety of GPCRs are affected by genetic variation that results in human pathology (reviewed in (20) and (19)) including variations in platelet GPCRs affecting platelet function (reviewed in (22)).

The detailed and systematic study of patients with bleeding disorders has continued to provide significant information regarding platelet GPCR function(23). Indeed the P2 $\mathrm{Y}_{12}$ receptor was initially cloned following the study of a patient with a bleeding history and a loss of function variation in the $P 2 Y 12 R$ gene that encodes $\mathrm{P}_{2} \mathrm{Y}_{12}(24)$. As part of the Genotyping and Phenotyping of Platelets consortium (GAPP) a series of rare genetic variations causing defects within platelet proteins(25), including GPCRs(22) have been identified. GAPP have recruited a cohort of patients with symptoms of mild, lifelong bleeding but no demonstrable defect in either platelet number or coagulation cascade function. The key signalling pathways responsible for loss of platelet function are studied in samples derived from individual patients. Knowledge of the defective pathways allows targeted sequencing of a subset of genes with the purpose of identifying LOF variants involved in forming the signalling pathway which may underlie the platelet dysfunction (26). Through this and similar patient-led phenotypic approaches, LOF variants in a number of platelet GPCRs including the P2Y 12 (see Figure 1 (27-32)), PAR4 (33) and TP- $\alpha$ receptors $(34,35)$ have been identified. Further detailed analysis of the 1,000 Genomes and ESP6500 databases has highlighted a host of potentially damaging variants in other platelet GPCR genes(23). Subsequent analysis of receptor function and expression of mutant receptor 
variants in model cell lines has ultimately provided significant information regarding structure-function relationships. Specific mutations have now been shown to affect platelet surface receptor expression, ligand binding, G protein-coupling, receptor internalization and receptor sorting (reviewed in (22) and (36)).

This review will concentrate on the consequences of mutations which specifically affect $\mathrm{P} 2 \mathrm{Y}_{12} \mathrm{R}$ surface expression, internalization and traffic that have in turn provided important insights into how these clinically important GPCRs function in vivo.

\section{The DRY motif: the case of the $R 122 C P 2 Y_{12}$ receptor variant}

Recently solved agonist- and antagonist-bound crystal structures of a number of GPCRs including the $\mathrm{P} 2 \mathrm{Y}_{12}$ receptor(37,38) (39)have significantly enhanced our understanding of ligand / receptor interaction and revealed an overall receptor activation mechanism (40,41). A number of conserved regions show distinct interaction patterns in the inactive receptor $(\mathrm{R})$ versus active receptor $\left(\mathrm{R}^{*}\right)$ conformations $(40,42,43)$. These motifs are believed to be critical regulators of the receptor activation process with one of these composed of the amino acids glutamic acid/aspartic acid- arginine-tyrosine, making up the E/DRY motif $(44,45)$. This motif is located at the boundary between transmembrane helix 3 (TM3) and intracellular loop 2 (ICL2) and is one of the most highly conserved in class A rhodopsin-like GPCRs with the arginine (Arg) being found in close to $100 \%$ of these receptors (44), including the $\mathrm{P}_{2} \mathrm{Y}_{12}$ receptor(45). The consensus derived mostly from studies on $\alpha_{1 \mathrm{~B}}$ and $\beta_{2}$ adrenoceptors is that the basic Arg forms a stabilizing intrahelical salt-bridge with the neighbouring Asp or Glu, and interhelical hydrogen bonds with another charged residue at the base of TM6, thereby constraining the GPCR in an inactive (R) conformation $(42,43)$.

The in vivo importance of the E/DRY motif was demonstrated in a patient who had a lifelong history of spontaneous bleeding, and haemorrhage upon surgical challenge (31). This patient who was homozygous for an Arg122Cys substitution within the DRY motif of the P2 $\mathrm{Y}_{12}$ receptor $(\mathrm{DRY} \rightarrow \mathrm{DCY})$ displayed significantly reduced platelet aggregation in response to ADP (see Figure 1). Further analysis of platelets derived from the patient revealed a significant reduction in surface $\mathrm{P} 2 \mathrm{Y}_{12}$ receptor expression. Two other class A GPCRs have also been identified with naturally occurring mutations in the central Arg of the DRY motif which include the vasopressin V2 (46) (47) and the gonadotropin-releasing hormone receptors $(\mathrm{GnRH})(48,49)$. In the case of the GnRH receptor, two mutations (Arg139His or Arg139Cys) result in a loss of agonist-stimulated receptor activity and hypogonadotropic 
hypogonadism in the patient. For mutations in the V2 vasopressin receptor, the situation is more complicated with mutations in the DRY motif leading to two different diseases with opposite clinical outcomes. An Arg137His mutation leads to nephrogenic diabetes insipidus (50), while an Arg137Cys/Lys mutation leads to a nephrogenic syndrome of inappropriate antidiuresis (46).

Intriguingly the $\mathrm{P}_{2} \mathrm{Y}_{12}$ receptor crystal structure shows that this receptor lacks some regulatory features conserved in many class A GPCRs. For example an "ionic lock" between the bottom of TM3 and TM6 seen in some GPCRs (51) is not present in the P2 $\mathrm{Y}_{12}$ receptor (37). This lock is thought to stabilise the inactive conformation of a GPCR in the absence of agonist ligand. In line with these structural observations, close examination of $\mathrm{P} 2 \mathrm{Y}_{12}$ receptor signalling in $1321 \mathrm{~N} 1$ cells shows that the receptor exhibits agonist-independent constitutive activity $(31,52)$. Over-expression of the $\mathrm{G}_{\mathrm{i}}$-coupled $\mathrm{P} 2 \mathrm{Y}_{12}$ receptor leads to an attenuation of forskolin-stimulated adenylate cyclase responsiveness in the absence of ADP (31) (52). This reduction in forskolin responsiveness is even more pronounced in cells expressing the Arg122Cys P2Y 12 variant receptor. Similarly the Arg137Cys/Lys variants of the V2 vasopressin receptor are also characterized by an elevated basal agonist-independent signal (53). Importantly ticagrelor is the only $\mathrm{P}_{2} \mathrm{Y}_{12}$ receptor antagonist to block the constitutive agonist-independent activity of the wild type $\mathrm{P} 2 \mathrm{Y}_{12}$ receptor and may contribute to the improved clinical efficacy of this antiplatelet drug versus other clinically used $\mathrm{P} 2 \mathrm{Y}_{12}$ receptor antagonists (52).

In relation to receptor traffic, the wild type $\mathrm{P}_{2} \mathrm{Y}_{12}$ receptor undergoes significant agonistindependent internalization where it colocalizes with transferrin, a marker for early and recycling endosomes (31). This pool of receptor, which recycles in a rab4-dependent manner, can readily recycle back to the cell surface (18). Whether like other platelet GPCRs $(54,55)$ this agonist-independent traffic may provide an internal pool of receptor able to mobilise to the cell surface and support receptor signalling requires further study. In cell lines the Arg122Cys $\mathrm{P}_{2} \mathrm{Y}_{12}$ receptor also internalizes in an agonist-independent manner although at a faster rate than the wild type receptor(31). Interestingly, mutation in the DRY motif of the V2 vasopressin receptor (Arg137His) promotes agonist-independent internalization followed by intracellular accumulation (50). Like the Arg137His vasopressin receptor, the Arg122Cys $\mathrm{P}^{2} \mathrm{Y}_{12}$ receptor variant undergoes rapid agonist-independent loss of surface receptor(31). When combined with signalling data outlined above, disruption of the DRY motif therefore appears to prevent stabilization of the $\mathrm{P}_{2} \mathrm{Y}_{12}$ and other GPCRs in an inactive conformation in 
the absence of agonist thereby enhancing agonist-independent receptor activity and internalization.

Following agonist-independent internalization a significant proportion of the Arg122Cys $\mathrm{P}_{2} \mathrm{Y}_{12}$ receptor variant, as in platelets, accumulates intracellularly (31). For many variant GPCRs, including in platelets variants of the TP thromboxane receptor (35) and PAR4(33), the receptor accumulates in the Golgi/ER suggestive of an impairment of receptor export. This was not the case with the Arg122Cys $\mathrm{P}_{2} \mathrm{Y}_{12}$ variant receptor with no evidence of colocalization with Golgi/ER markers. In fact, the Arg122Cys $\mathrm{P}_{2} \mathrm{Y}_{12}$ receptor variant is targeted to a distinct endocytic compartment, where unlike the wild type $\mathrm{P}_{2} \mathrm{Y}_{12}$ receptor, it colocalizes with lysosomal markers (31). The specific molecular regulators of this process are currently unknown. The variant does possess a novel cysteine that could lead to the introduction of novel disulfide cysteine-cysteine intramolecular bonds potentially promoting this aberrant traffic. However no obvious differences in molecular masses of the Arg122Cys P2 $\mathrm{Y}_{12}$ receptor have been reported which would preclude lack of novel protein-protein bonds. Further there are no obvious interaction motifs that could explain changes in receptor trafficking that are proximal to the DRY motif. Given the large number of interacting proteins that could potentially regulate the Arg122Cys $\mathrm{P}_{2} \mathrm{Y}_{12}$ variant being preferentially targetted to lysosomes (56), further detailed cellular studies are still required to address this question.

\section{The integrity of the PDZ-binding motif of the $P 2 Y_{12} R$ is essential for normal platelet receptor function}

A number of SNPs within GPCRs appear to modulate agonist-dependent receptor traffic. For example in the human $\beta_{1}$-adrenoceptor Ser49Gly, a SNP located in the N-terminus, displays a distinct trafficking phenotype (57) with the variant exhibiting increased basal and agoniststimulated adenylyl cyclase activity as well as enhanced agonist-induced downregulation (58). For the $\beta_{2}$-adrenoceptor the picture is more complex with an Arg16Gly variant receptor displaying enhanced agonist-promoted downregulation whilst a Gln27Glu polymorphism is resistant to degradation (reviewed in (59). Such SNPs that can alter agonist-dependent traffic have the potential to impact upon pharmacotherapy directed at these GPCRs. For example the Arg16Gly $\beta_{2}$-adrenoceptor receptor, which is associated with reduced lung function and familial nocturnal asthma, is also commonly resistant to some $\beta_{2}$-adrenoceptor agonists (60). 
This agonist resistance has been attributed to enhanced agonist-induced receptor loss. Similarly a variant of the $\mu$-opioid receptor (L83I) morphine is more liable to internalize in response to morphine, unlike the wild-type receptor that undergoes significantly less morphine-stimulated internalization (61). The presence of this SNP within an individual may consequently affect the development of tolerance and analgesic responses. Therefore SNPs which can affect normal agonist-stimulated changes in surface receptor expression have the potential to alter drug responsiveness.

In relation to the platelet $\mathrm{P} 2 \mathrm{Y}_{12}$ receptor, a particularly novel mutation identified through GAPP was in a patient with mild bleeding who was heterozygous for a Pro341Ala substitution (32). This SNP was of particular interest since the mutation is located within a putative postsynaptic density 95/disc large/zonula occludens-1 (PDZ) binding sequence at the extreme $\mathrm{C}$ terminus of the $\mathrm{P} 2 \mathrm{Y}_{12}$ receptor (see Figure 1). PDZ ligands consist of a short amino acid sequence and are found at the extreme $\mathrm{C}$-terminus of a large number of proteins including more than 30 GPCRs $(56,62)$. These ligands can bind to a number of PDZ domaincontaining regulatory proteins with these interactions regulating various aspects of receptor function including stabilization, signaling and trafficking $(62,63)$. $\mathrm{P} 2 \mathrm{Y}_{12}$ receptor signalling and ligand binding was significantly diminished in platelets expressing the Pro341Ala variant(32). Despite a large number of cell line studies which have highlighted the importance of PDZ interactions (62), this was the first report of a naturally occurring mutation in a PDZ ligand in vivo demonstrating the importance of this motif to receptor function. Further study revealed that alongside deficits in receptor function, agonistdependent $\mathrm{P} 2 \mathrm{Y}_{12}$ receptor traffic was also significantly compromised in platelets expressing the Pro341Ala variant. Accompanying this change in receptor traffic, agonist-induced changes in receptor activity were also abrogated with minimal resensitization of receptor function following ADP-stimulated receptor desensitization.

Subsequent studies in cells transfected with the variant Pro341Ala P2Y 12 receptor revealed that the variant receptor was retained intracellularly in a rab-7 positive compartment which colocalized with markers of the trans-Golgi network (TGN). The Pro341Ala P2 $\mathrm{Y}_{12}$ receptor was not able to recycle and resensitize following agonist exposure $(18,32)$. This was in contrast to the wild type receptor which recycles back to the cell surface in a rab4/11dependent manner rapidly following agonist-dependent internalization facilitating receptor resensitization (18). Therefore the integrity of the PDZ-ligand of the $\mathrm{P}_{2} \mathrm{Y}_{12}$ receptor was essential for normal agonist-induced traffic. 


\section{PDZ-binding proteins play an essential role in maintaining platelet $P 2 Y_{12} R$ activity}

Given the in vivo demonstration of the critical importance of the PDZ-binding motif, a subsequent proteomic screen revealed a series of binding partners that specifically interacted with the C-terminus of the $\mathrm{P}_{2} \mathrm{Y}_{12}$ receptor including the PDZ-binding protein, $\mathrm{Na}+\mathrm{H}+$ exchanger regulatory factor (NHERF). Interestingly the PDZ ligand and the presence of the Pro341 residue limited the number of proteins capable of interacting with the $\mathrm{P} 2 \mathrm{Y}_{12}$ receptor, with a significant increase in binding partners following its substitution (M.R. Cunningham and S.J. Mundell, unpublished work). This result would imply that the integrity of the PDZ ligand is essential for recognition by a specific subset of PDZ domain-containing proteins that regulate receptor function and may well explain the differential endosomal sorting of the Pro341Ala -variant $(18,32)$. Addition of a CFP-tag onto the C-terminus of the receptor also alters the complement and number of $\mathrm{P}_{2} \mathrm{Y}_{12}$ receptor interacting partners (M.R. Cunningham and S.J. Mundell, unpublished work) highlighting the potential pitfalls of adding bulky proteins onto the C-terminus of a GPCR.

Further studies have confirmed the ability of NHERF isoforms (NHERF1 and NHERF2) to bind specifically to the C-tail PDZ ligand of the $\mathrm{P}_{2} \mathrm{Y}_{12}$ receptor (64), thus supporting the proteomic screen. These proteins have now been shown to regulate the surface expression and activity of numerous GPCRs (65). NHERF1 interacts basally with the $\mathrm{P} 2 \mathrm{Y}_{12}$ receptor in a PDZ-dependent manner with agonist addition increasing $\mathrm{P}_{2} \mathrm{Y}_{12}$ receptor / NHERF association that is required for agonist-stimulated receptor internalization(64). Intriguingly agonistdependent association of the $\mathrm{P}_{2} \mathrm{Y}_{12}$ receptor with NHERF was PDZ ligand-independent and required arrestin-receptor interaction. This study was therefore the first to directly demonstrate arrestin-dependent recruitment of NHERF1 to a receptor following agonist treatment. The in vivo significance of the NHERF-P2 $\mathrm{Y}_{12}$ receptor interaction is ongoing in NHERF1 (-/-), NHERF2 (-/-) and NHERF1/2 (-/-) mice. These studies corroborate findings in cell line models showing that NHERF protein isoforms can regulate endogenous platelet $\mathrm{P}_{2} \mathrm{Y}_{12}$ receptor surface expression and activity (Cunningham et al., paper in preparation). The ability of other PDZ- and NHERF-interacting proteins to bind and regulate $\mathrm{P} 2 \mathrm{Y}_{12}$ receptor function is currently under investigation.

Variations in GPCR accessory proteins and their links to disease 
The identification of genetic variants in key proteins that are essential for GPCR activity has also provided important insights into their functional significance. There are many examples of genetic variations in accessory proteins that disrupt receptor function linked to disease. Examples include variants of $\mathrm{G} \beta$ subunits which are linked to essential hypertension, obesity, stroke, and myocardial infarction or variants of regulators $G$ protein signalling (RGS) protein that confer risk for essential hypertension through changes in dopamine D1 receptormediated kidney function (reviewed in (66).

In relation to GRKs, which are established regulators of GPCR activity and traffic, both human GRK2 and GRK3 genes appear to lack genetic variation in their coding regions whilst GRK4 and GRK5 possess variations that have significant functional impacts (reviewed in (67)). Variants of GRK4, altering dopamine $\mathrm{D}_{1}$ receptor-mediated kidney function, have been identified as playing a role in essential hypertension (68) (69). Expression of three GRK4 SNPs (Arg65Leu, Ala142Val, and Ala486Val) increased basal phosphorylation of the dopamine $\mathrm{D}_{1}$ receptor and impaired receptor-mediated cAMP production (70). Further in vitro studies suggest that the GRK4 SNPs disrupt the function of dopamine $\mathrm{D}_{1}$ receptors (71) (72), increase blood pressure, and impair the diuretic and natriuretic effects of dopamine $\mathrm{D}_{1}$ receptor stimulation (73). In addition to abnormal desensitization of the dopamine $D_{1}$ receptor, GRK4 polymorphisms are associated with increased expression of the angiotensin II type 1 receptor, which is another regulator of sodium load (74).

A GRK5 variant (Leu41Gln), which displays an enhanced ability to promote agonistdependent $\beta 1$ and $\beta 2$ adrenoceptor desensitization and internalization, has been shown to be involved in accelerated termination of $\beta$-adrenoceptor-induced cardiac contractility, improved protection against cardiac $\beta$-adrenoceptor overstimulation, better response to $\beta$-blockers and improved survival in heart failure $(75,76)$. Interestingly in GRK5, this polymorphism is adjacent to a calmodulin-binding domain (77) which, following calcium-calmodulin binding, is reported to inhibit GRK5 catalytic activity towards receptors.

Beyond GRKs, variations in other proteins known to regulate GPCR traffic have also been reported. Unlike the examples of GRK isoforms above, GPCRs share common endocytic trafficking of many cell surface expressed proteins. Therefore it is perhaps not surprising that specific mutations in key regulatory machinery components have more global effects on a plethora of cell surface cargo cell rather than just specific GPCRs. For example, sorting nexin 27 (SNX27) is a known regulator of endosomal recycling of specific PDZ ligand-containing 
cargo proteins including a number of GPCRs such as the $\beta 2$-adrenoceptor, $5 \mathrm{HT}_{2}$ receptor and parathyroid hormone receptor (78-80). Detailed proteomic analysis conducted in mammalian cell lines has revealed that a loss of SNX27 expression results in the downregulation of multiple membrane proteins (81). Recent evidence has linked mutations in the SNX27 gene to Down's syndrome and infantile myoclonic epilepsy (82) (83). The molecular mechanism of Down's syndrome (DS) pathogenesis, particularly cognitive defects in DS mice models, are thought to be due to loss of SNX27 expression and the subsequent downregulation of membrane glutamate NMDA and AMPA receptors(82).

Similarly mutations in the GTPase dynamin 2, which again regulates the membrane traffic of multiple cell surface proteins including that of GPCRs, are associated with a number of disorders including Charcot-Marie- Tooth (CMT), peripheral neuropathy and centronuclear myopathy (CNM) $(84,85)$. These two genetically heterogeneous disorders, which are both associated with general skeletal muscle weakness, have differing pathophysiological origins. Intriguingly close examination of the location of specific mutations in dynamin-2 revealed that most CNM mutations cluster in the interface between the dynamin mid-domain and pleckstrin homology domain of dynamin-2, thus altering the autoinhibitory interface between these domains thereby supporting a gain-of-function mechanism (86). The CMT mutations meanwhile are predominantly located on phosphoinositide-binding PH domain loops which are essential for targeting dynamin-2 to the plasma membrane (87). Given that the dynamin2 knockout mouse is embryonic lethal (88), when combined, these studies suggest that mutations found in humans do not completely abolish dynamin-2 protein function, but rather involve subtle functional changes that lead to the progressive pathologies seen in CMT and CMN. Notably the examples of both SNX27 and dynamin-2 have validated the key physiological importance of these proteins and helped to validate the functional significance of key domains predicted to regulate their biology.

Intriguingly given that arrestins play keys roles in receptor biology, very few genetic polymorphisms have been identified (67). Some evidence has emerged that associates noncoding variations in the non-visual arrestin gene with the risk of developing major depressive disorder (89) and the pathogenesis of Alzheimer's disease (90). So far coding polymorphisms with significant functional impact have only been discovered in the visual arrestin-1 gene, which lead to visual disorders (e.g., Oguchi's disease(91), night blindness or retinitis pigmentosa(92)). Given both the physiological importance of the arrestin family in the regulation of the majority of GPCRs and that there are only two isoforms of the non-visual 
arrestins, perhaps it is not surprising that evolution may not have allowed for high levels of genetic variation of these proteins seen in GPCRs.

A number of SNPs linked to platelet GPCR function and traffic have been identified during the course of the GAPP study (unpublished data). These include variants in dynamin-2 and NHERF1. Further study is now required to determine the functional significance of these SNPs in relation to platelet GPCR function.

\section{Conclusions and future perspectives}

As highlighted above with studies on the $\mathrm{P}^{2} \mathrm{Y}_{12}$ receptor, the investigation of naturally occurring GPCR variants continues to provide invaluable insights into the role of specific receptors as genetic risk factors for disease and the prediction of altered drug response. Mutated forms of GPCRs resulting in the disruption of receptor function are associated with a wide variety of human genetic diseases, including mild platelet bleeding disorders. In human platelets such naturally occurring variations have provided a unique opportunity to study amino acid substitutions endogenously expressed in human tissue. In this regard, platelets have a distinct advantage over other cell types in that they can be taken repeatedly and with relative ease from patients and family members. Monogenic disorders resulting from disrupted GPCR function and signalling provide a unique window on receptor function. This complements the plethora of data available from in vitro studies of variant receptors that have assigned structure-function relationships to particular receptor motifs. For example, in relation to the $\mathrm{P} 2 \mathrm{Y}_{12}$ receptor rare variants, disrupting either the DRY or PDZ motifs have both been shown to affect endogenous receptor traffic and function in platelets. Such essential "in vivo" validation has enabled the full translation of our knowledge and understanding of receptor traffic in cell line studies into relevant human biological systems.

The identification of naturally occurring variants in accessory proteins that regulate GPCR traffic and function is ongoing. Inherent difficulties have limited our ability to translate our current understanding of the role of specific molecular regulators of receptor function from cell expression studies into animal models and then into man. For example significant differences in cell machinery, membrane trafficking and receptor expression levels exist in individual cell types. Further, technologies emerging from next-generation sequencing continue to generate significant datasets for integrating genomic information into pharmacogenomic studies. For example RNA-sequencing, which makes use of nextgeneration sequencing to assess RNA presence and quantity at a given time will enable the 
simultaneous profiling of multiple readouts including splice variants, expressed genes and RNA-edited isoforms. Such developments will significantly add to the already large list of protein variants, including those in GPCRs and their regulators identified over the past two decades. Whether specific genetic variations in key regulators of GPCR activity and traffic will provide an adjunct to the conventional routes of translating in vitro cell line studies into an in vivo physiologically relevant setting remains a potentially exciting opportunity to be fully realized.

\section{Acknowledgements}

The authors thank Professor Eamonn Kelly for critical reading of this manuscript. Work was supported by Senior British Heart Foundation Research Fellowship awarded to SJM FS/11/49/28751. 


\section{References}

1. Hechler B, Gachet C. Purinergic Receptors in Thrombosis and Inflammation. Arteriosclerosis, thrombosis, and vascular biology. 2015;35(11):2307-2315.

2. Mitchell JA, Ali F, Bailey L, Moreno L, Harrington LS. Role of nitric oxide and prostacyclin as vasoactive hormones released by the endothelium. Experimental physiology. 2008;93(1):141-147.

3. Bye AP, Unsworth AJ, Gibbins JM. Platelet signaling: a complex interplay between inhibitory and activatory networks. Journal of thrombosis and haemostasis : JTH. 2016;14(5):918-930.

4. Offermanns S. Activation of platelet function through $\mathrm{G}$ protein-coupled receptors. Circulation research. 2006;99(12):1293-1304.

5. Jin J, Kunapuli SP. Coactivation of two different $G$ protein-coupled receptors is essential for ADP-induced platelet aggregation. Proc Natl Acad Sci U S A. 1998;95:8070-8074.

6. Shankar H, Garcia A, Prabhakar J, Kim S, Kunapuli SP. P2Y12 receptor-mediated potentiation of thrombin-induced thromboxane $A 2$ generation in platelets occurs through regulation of Erk1/2 activation. Journal of thrombosis and haemostasis : JTH. 2006;4(3):638-647.

7. Laine M, Paganelli F, Bonello L. P2Y12-ADP receptor antagonists: Days of future and past. World journal of cardiology. 2016;8(5):327-332.

8. Baurand A, Eckly A, Hechler B, Kauffenstein G, Galzi JL, Cazenave JP, Leon C, Gachet C. Differential regulation and relocalization of the platelet $P 2 Y$ receptors after activation: a way to avoid loss of hemostatic properties? Molecular pharmacology. 2005;67(3):721-733.

9. Hardy AR, Conley PB, Luo J, Benovic JL, Poole AW, Mundell SJ. P2Y1 and P2Y12 receptors for ADP desensitize by distinct kinase-dependent mechanisms. Blood. 2005;105(9):3552-3560. Epub 2005 Jan 3521.

10. Baurand A, Eckly A, Bari N, Leon C, Hechler B, Cazenave JP, Gachet C. Desensitization of the platelet aggregation response to ADP: differential down-regulation of the P2Y1 and P2cyc receptors. Thromb Haemost. 2000;84:484-491.

11. Mundell SJ, Barton JF, Mayo-Martin MB, Hardy AR, Poole AW. Rapid resensitization of purinergic receptor function in human platelets. Journal of thrombosis and haemostasis : JTH. 2008;6(8):1393-1404.

12. Cunningham MR, Nisar SP, Mundell SJ. Molecular mechanisms of platelet P2Y(12) receptor regulation. Biochemical Society transactions. 2013;41(1):225-230.

13. Hardy AR, Conley PB, Luo J, Benovic JL, Poole AW, Mundell SJ. P2Y1 and P2Y12 receptors for ADP desensitize by distinct kinase-dependent mechanisms. Blood. 2005;105(9):3552-3560.

14. Mundell SJ, Luo J, Benovic JL, Conley PB, Poole AW. Distinct clathrin-coated pits sort different G protein-coupled receptor cargo. Traffic. 2006;7(10):1420-1431. Epub 2006 Aug 1410.

15. Puthenveedu MA, von Zastrow M. Cargo regulates clathrin-coated pit dynamics. Cell. 2006;127(1):113-124.

16. Kanamarlapudi V, Owens SE, Saha K, Pope RJ, Mundell SJ. ARF6-dependent regulation of P2Y receptor traffic and function in human platelets. PloS one. 2012;7(8):e43532.

17. Ferreira F, Foley M, Cooke A, Cunningham M, Smith G, Woolley R, Henderson G, Kelly E, Mundell S, Smythe E. Endocytosis of $G$ protein-coupled receptors is regulated by clathrin light chain phosphorylation. Current biology : CB. 2012;22(15):1361-1370.

18. Cunningham MR, Nisar SP, Cooke AE, Emery ED, Mundell SJ. Differential endosomal sorting of a novel P2Y12 purinoreceptor mutant. Traffic. 2013;14(5):585-598. 
19. Thompson MD, Cole DE, Capra V, Siminovitch KA, Rovati GE, Burnham WM, Rana BK. Pharmacogenetics of the $\mathrm{G}$ protein-coupled receptors. Methods in molecular biology. 2014;1175:189-242.

20. Thompson MD, Hendy GN, Percy ME, Bichet DG, Cole DE. G protein-coupled receptor mutations and human genetic disease. Methods in molecular biology. 2014;1175:153-187.

21. Stoy H, Gurevich VV. How genetic errors in GPCRs affect their function: Possible therapeutic strategies. Genes \& diseases. 2015;2(2):108-132.

22. Nisar SP, Jones ML, Cunningham MR, Mumford AD, Mundell SJ, Group UGS. Rare platelet GPCR variants: what can we learn? British journal of pharmacology. 2015;172(13):32423253.

23. Jones ML, Norman JE, Morgan NV, Mundell SJ, Lordkipanidze M, Lowe GC, Daly ME, Simpson MA, Drake S, Watson SP, Mumford AD, group UGs. Diversity and impact of rare variants in genes encoding the platelet $\mathrm{G}$ protein-coupled receptors. Thrombosis and haemostasis. 2015;113(4):826-837.

24. Hollopeter G, Jantzen HM, Vincent D, Li G, England L, Ramakrishan V, Yang RB, Nurden A, Julius $\mathrm{D}$, Conley $\mathrm{PB}$. Identification of the platelet ADP receptor targeted by antithrombotic drugs. Nature. 2001;409:202-207.

25. Watson S, Daly M, Dawood B, Gissen P, Makris M, Mundell S, Wilde J, Mumford A. Phenotypic approaches to gene mapping in platelet function disorders - identification of new variant of P2Y12, TxA2 and GPVI receptors. Hamostaseologie. 2010;30(1):29-38.

26. Leo VC, Morgan NV, Bem D, Jones ML, Lowe GC, Lordkipanidze M, Drake S, Simpson MA, Gissen P, Mumford A, Watson SP, Daly ME, Group UGS. Use of next-generation sequencing and candidate gene analysis to identify underlying defects in patients with inherited platelet function disorders. Journal of thrombosis and haemostasis : JTH. 2015;13(4):643-650.

27. Cattaneo M, Zighetti ML, Lombardi R, Martinez C, Lecchi A, Conley PB, Ware J, Ruggeri ZM. Molecular bases of defective signal transduction in the platelet $\mathrm{P} 2 \mathrm{Y} 12$ receptor of a patient with congenital bleeding. Proceedings of the National Academy of Sciences of the United States of America. 2003;100(4):1978-1983.

28. Remijn JA, MJ IJ, Strunk AL, Abbes AP, Engel H, Dikkeschei B, Dompeling EC, de Groot PG, Slingerland RJ. Novel molecular defect in the platelet ADP receptor P2Y12 of a patient with haemorrhagic diathesis. Clin Chem Lab Med. 2007;45(2):187-189.

29. Daly ME, Dawood BB, Lester WA, Peake IR, Rodeghiero F, Goodeve AC, Makris M, Wilde JT, Mumford AD, Watson SP, Mundell SJ. Identification and characterization of a novel P2Y 12 variant in a patient diagnosed with type 1 von Willebrand disease in the European MCMDM1VWD study. Blood. 2009;113(17):4110-4113.

30. Lecchi A, Razzari C, Paoletta S, Dupuis A, Nakamura L, Ohlmann P, Gachet C, Jacobson KA, Zieger B, Cattaneo M. Identification of a new dysfunctional platelet P2Y12 receptor variant associated with bleeding diathesis. Blood. 2015;125(6):1006-1013.

31. Patel YM, Lordkipanidze M, Lowe GC, Nisar SP, Garner K, Stockley J, Daly ME, Mitchell M, Watson SP, Austin SK, Mundell SJ. A novel mutation in the p2y receptor and a functionreducing polymorphism in par-1 in a patient with chronic bleeding. Journal of thrombosis and haemostasis : JTH. 2014.

32. Nisar S, Daly ME, Federici AB, Artoni A, Mumford AD, Watson SP, Mundell SJ. An intact PDZ motif is essential for correct $\mathrm{P} 2 \mathrm{Y} 12$ purinoceptor traffic in human platelets. Blood. 2011;118(20):5641-5651.

33. Norman JE, Cunningham MR, Jones ML, Walker ME, Westbury SK, Sessions RB, Mundell SJ, Mumford AD. p.Tyr157Cys Variant in Protease-Activated Receptor 4 Reduces Platelet Functional Responses and Alters Receptor Trafficking. Arteriosclerosis, thrombosis, and vascular biology. 2016. 
34. Mumford AD, Dawood BB, Daly ME, Murden SL, Williams MD, Protty MB, Spalton JC, Wheatley M, Mundell SJ, Watson SP. A novel thromboxane A2 receptor D304N variant that abrogates ligand binding in a patient with a bleeding diathesis. Blood. 2010;115(2):363-369.

35. Nisar SP, Lordkipanidze M, Jones ML, Dawood B, Murden S, Cunningham MR, Mumford AD, Wilde JT, Watson SP, Mundell SJ, Lowe GC, on behalf of the UKGsg. A novel thromboxane A2 receptor N42S variant results in reduced surface expression and platelet dysfunction.

Thrombosis and haemostasis. 2014;111(5).

36. Lecchi A, Femia EA, Paoletta S, Dupuis A, Ohlmann P, Gachet C, Jacobson KA, Machura K, Podda GM, Zieger B, Cattaneo M. Inherited dysfunctional platelet $\mathrm{P} 2 \mathrm{Y} 12$ receptor mutations associated with bleeding disorders. Hamostaseologie. 2016;36(4).

37. Zhang J, Zhang K, Gao ZG, Paoletta S, Zhang D, Han GW, Li T, Ma L, Zhang W, Muller CE, Yang $\mathrm{H}$, Jiang $\mathrm{H}$, Cherezov V, Katritch V, Jacobson KA, Stevens RC, Wu B, Zhao Q. Agonist-bound structure of the human P2Y12 receptor. Nature. 2014;509(7498):119-122.

38. Zhang K, Zhang J, Gao ZG, Zhang D, Zhu L, Han GW, Moss SM, Paoletta S, Kiselev E, Lu W, Fenalti G, Zhang W, Muller CE, Yang H, Jiang H, Cherezov V, Katritch V, Jacobson KA, Stevens RC, Wu B, Zhao Q. Structure of the human P2Y12 receptor in complex with an antithrombotic drug. Nature. 2014;509(7498):115-118.

39. Lu M, Wu B. Structural studies of $G$ protein-coupled receptors. IUBMB life. 2016;68(11):894903.

40. Hulme EC. GPCR activation: a mutagenic spotlight on crystal structures. Trends in pharmacological sciences. 2013;34(1):67-84.

41. Manglik A, Kobilka B. The role of protein dynamics in GPCR function: insights from the beta2AR and rhodopsin. Current opinion in cell biology. 2014;27:136-143.

42. Salon JA, Lodowski DT, Palczewski K. The significance of G protein-coupled receptor crystallography for drug discovery. Pharmacological reviews. 2011;63(4):901-937.

43. Nygaard R, Frimurer TM, Holst B, Rosenkilde MM, Schwartz TW. Ligand binding and microswitches in 7TM receptor structures. Trends in pharmacological sciences. 2009;30(5):249259.

44. Rovati GE, Capra V, Neubig RR. The highly conserved DRY motif of class A G protein-coupled receptors: beyond the ground state. Molecular pharmacology. 2007;71(4):959-964.

45. Rovati GE, Capra V. The DRY motif at work: the P2Y12 receptor case. Journal of thrombosis and haemostasis : JTH. 2014;12(5):713-715.

46. Rosenthal W, Antaramian A, Gilbert S, Birnbaumer M. Nephrogenic diabetes insipidus. A V2 vasopressin receptor unable to stimulate adenylyl cyclase. The Journal of biological chemistry. 1993;268(18):13030-13033.

47. Feldman BJ, Rosenthal SM, Vargas GA, Fenwick RG, Huang EA, Matsuda-Abedini M, Lustig RH, Mathias RS, Portale AA, Miller WL, Gitelman SE. Nephrogenic syndrome of inappropriate antidiuresis. The New England journal of medicine. 2005;352(18):1884-1890.

48. Topaloglu AK, Lu ZL, Farooqi IS, Mungan NO, Yuksel B, O'Rahilly S, Millar RP. Molecular genetic analysis of normosmic hypogonadotropic hypogonadism in a Turkish population: identification and detailed functional characterization of a novel mutation in the gonadotropin-releasing hormone receptor gene. Neuroendocrinology. 2006;84(5):301-308.

49. Costa EM, Bedecarrats GY, Mendonca BB, Arnhold IJ, Kaiser UB, Latronico AC. Two novel mutations in the gonadotropin-releasing hormone receptor gene in Brazilian patients with hypogonadotropic hypogonadism and normal olfaction. The Journal of clinical endocrinology and metabolism. 2001;86(6):2680-2686.

50. Barak LS, Oakley RH, Laporte SA, Caron MG. Constitutive arrestin-mediated desensitization of a human vasopressin receptor mutant associated with nephrogenic diabetes insipidus. Proceedings of the National Academy of Sciences of the United States of America. 2001;98(1):93-98. 
51. Latorraca NR, Venkatakrishnan AJ, Dror RO. GPCR Dynamics: Structures in Motion. Chemical reviews. 2016.

52. Aungraheeta R, Conibear A, Butler M, Kelly E, Nylander S, Mumford A, Mundell S. Inverse agonism at the P2Y12 receptor and ENT1 transporter blockade contribute to platelet inhibition by ticagrelor. Blood. 2016.

53. Rochdi MD, Vargas GA, Carpentier E, Oligny-Longpre G, Chen S, Kovoor A, Gitelman SE, Rosenthal SM, von Zastrow M, Bouvier M. Functional characterization of vasopressin type 2 receptor substitutions (R137H/C/L) leading to nephrogenic diabetes insipidus and nephrogenic syndrome of inappropriate antidiuresis: implications for treatments. Molecular pharmacology. 2010;77(5):836-845.

54. Paing MM, Johnston CA, Siderovski DP, Trejo J. Clathrin adaptor AP2 regulates thrombin receptor constitutive internalization and endothelial cell resensitization. Mol Cell Biol. 2006;26(8):3231-3242.

55. Parent JL, Labrecque $P$, Rochdi MD, Benovic JL. Role of the differentially spliced carboxyl terminus in thromboxane $A 2$ receptor trafficking: identification of a distinct motif for tonic internalization. The Journal of biological chemistry. 2001;276:7079-7085.

56. Marchese A, Paing MM, Temple BR, Trejo J. G protein-coupled receptor sorting to endosomes and lysosomes. Annu Rev Pharmacol Toxicol. 2008;48:601-629.

57. Maqbool A, Hall AS, Ball SG, Balmforth AJ. Common polymorphisms of beta1-adrenoceptor: identification and rapid screening assay. Lancet. 1999;353(9156):897.

58. Levin MC, Marullo S, Muntaner $\mathrm{O}$, Andersson B, Magnusson $\mathrm{Y}$. The myocardium-protective Gly-49 variant of the beta 1-adrenergic receptor exhibits constitutive activity and increased desensitization and down-regulation. The Journal of biological chemistry. 2002;277(34):30429-30435.

59. Leineweber K, Heusch G. Beta 1- and beta 2-adrenoceptor polymorphisms and cardiovascular diseases. British journal of pharmacology. 2009;158(1):61-69.

60. Small KM, McGraw DW, Liggett SB. Pharmacology and physiology of human adrenergic receptor polymorphisms. Annual review of pharmacology and toxicology. 2003;43:381-411.

61. Cooke AE, Oldfield S, Krasel C, Mundell SJ, Henderson G, Kelly E. Morphine-induced internalization of the L83I mutant of the rat mu-opioid receptor. British journal of pharmacology. 2015;172(2):593-605.

62. Romero $\mathrm{G}$, von Zastrow $\mathrm{M}$, Friedman PA. Role of PDZ proteins in regulating trafficking, signaling, and function of GPCRs: means, motif, and opportunity. Adv Pharmacol. 2011;62:279-314.

63. Weinman EJ, Hall RA, Friedman PA, Liu-Chen LY, Shenolikar S. The association of NHERF adaptor proteins with g protein-coupled receptors and receptor tyrosine kinases. Annu Rev Physiol. 2006;68:491-505.

64. Nisar SP, Cunningham M, Saxena K, Pope RJ, Kelly E, Mundell SJ. Arrestin scaffolds NHERF1 to the $\mathrm{P} 2 \mathrm{Y} 12$ receptor to regulate receptor internalization. The Journal of biological chemistry. 2012;287(29):24505-24515.

65. Ardura JA, Friedman PA. Regulation of $\mathrm{G}$ protein-coupled receptor function by $\mathrm{Na}+/ \mathrm{H}+$ exchange regulatory factors. Pharmacological reviews. 2011;63(4):882-900.

66. Thompson MD, Cole DE, Jose PA, Chidiac P. G protein-coupled receptor accessory proteins and signaling: pharmacogenomic insights. Methods in molecular biology. 2014;1175:121152.

67. Lymperopoulos A, Bathgate A. Pharmacogenomics of the heptahelical receptor regulators Gprotein-coupled receptor kinases and arrestins: the known and the unknown.

Pharmacogenomics. 2012;13(3):323-341.

68. Felder RA, Sanada H, Xu J, Yu PY, Wang Z, Watanabe H, Asico LD, Wang W, Zheng S, Yamaguchi I, Williams SM, Gainer J, Brown NJ, Hazen-Martin D, Wong LJ, Robillard JE, Carey RM, Eisner GM, Jose PA. G protein-coupled receptor kinase 4 gene variants in human 
essential hypertension. Proceedings of the National Academy of Sciences of the United States of America. 2002;99(6):3872-3877.

69. Sanada H, Yoneda M, Yatabe J, Williams SM, Bartlett J, White MJ, Gordon LN, Felder RA, Eisner GM, Armando I, Jose PA. Common variants of the G protein-coupled receptor type 4 are associated with human essential hypertension and predict the blood pressure response to angiotensin receptor blockade. The pharmacogenomics journal. 2016;16(1):3-9.

70. Watanabe $\mathrm{H}, \mathrm{Xu}$ J, Bengra $\mathrm{C}$, Jose PA, Felder RA. Desensitization of human renal D1 dopamine receptors by $\mathrm{G}$ protein-coupled receptor kinase 4. Kidney international. 2002;62(3):790-798.

71. Rankin ML, Marinec PS, Cabrera DM, Wang Z, Jose PA, Sibley DR. The D1 dopamine receptor is constitutively phosphorylated by $\mathrm{G}$ protein-coupled receptor kinase 4 . Molecular pharmacology. 2006;69(3):759-769.

72. Yu P, Asico LD, Luo Y, Andrews P, Eisner GM, Hopfer U, Felder RA, Jose PA. D1 dopamine receptor hyperphosphorylation in renal proximal tubules in hypertension. Kidney international. 2006;70(6):1072-1079.

73. Felder RA, Jose PA. Mechanisms of disease: the role of GRK4 in the etiology of essential hypertension and salt sensitivity. Nature clinical practice Nephrology. 2006;2(11):637-650.

74. Chen K, Fu C, Chen C, Liu L, Ren H, Han Y, Yang J, He D, Zhou L, Yang Z, Zhang L, Jose PA, Zeng C. Role of GRK4 in the regulation of arterial AT1 receptor in hypertension. Hypertension. 2014;63(2):289-296.

75. Liggett SB, Cresci S, Kelly RJ, Syed FM, Matkovich SJ, Hahn HS, Diwan A, Martini JS, Sparks L, Parekh RR, Spertus JA, Koch WJ, Kardia SL, Dorn GW, 2nd. A GRK5 polymorphism that inhibits beta-adrenergic receptor signaling is protective in heart failure. Nature medicine. 2008;14(5):510-517.

76. Wang WC, Mihlbachler KA, Bleecker ER, Weiss ST, Liggett SB. A polymorphism of G-protein coupled receptor kinase 5 alters agonist-promoted desensitization of beta2-adrenergic receptors. Pharmacogenetics and genomics. 2008;18(8):729-732.

77. Pronin AN, Satpaev DK, Slepak VZ, Benovic JL. Regulation of G protein-coupled receptor kinases by calmodulin and localization of the calmodulin binding domain. The Journal of biological chemistry. 1997;272(29):18273-18280.

78. Joubert L, Hanson B, Barthet G, Sebben M, Claeysen S, Hong W, Marin P, Dumuis A, Bockaert J. New sorting nexin (SNX27) and NHERF specifically interact with the 5-HT4a receptor splice variant: roles in receptor targeting. Journal of cell science. 2004;117(Pt 22):5367-5379.

79. Lauffer BE, Melero C, Temkin P, Lei C, Hong W, Kortemme T, von Zastrow M. SNX27 mediates PDZ-directed sorting from endosomes to the plasma membrane. J Cell Biol. 2010;190(4):565-574.

80. McGarvey JC, Xiao K, Bowman SL, Mamonova T, Zhang Q, Bisello A, Sneddon WB, Ardura JA, Jean-Alphonse F, Vilardaga JP, Puthenveedu MA, Friedman PA. Actin-Sorting Nexin 27 (SNX27)-Retromer Complex Mediates Rapid Parathyroid Hormone Receptor Recycling. The Journal of biological chemistry. 2016;291(21):10986-11002.

81. Steinberg F, Gallon M, Winfield M, Thomas EC, Bell AJ, Heesom KJ, Tavare JM, Cullen PJ. A global analysis of SNX27-retromer assembly and cargo specificity reveals a function in glucose and metal ion transport. Nature cell biology. 2013;15(5):461-471.

82. Wang $X$, Zhao $Y$, Zhang $X$, Badie $H$, Zhou Y, Mu Y, Loo LS, Cai L, Thompson RC, Yang B, Chen Y, Johnson PF, Wu C, Bu G, Mobley WC, Zhang D, Gage FH, Ranscht B, Zhang YW, Lipton SA, Hong $\mathrm{W}, \mathrm{Xu} \mathrm{H}$. Loss of sorting nexin 27 contributes to excitatory synaptic dysfunction by modulating glutamate receptor recycling in Down's syndrome. Nature medicine. 2013;19(4):473-480.

83. Damseh N, Danson CM, Al-Ashhab M, Abu-Libdeh B, Gallon M, Sharma K, Yaacov B, Coulthard E, Caldwell MA, Edvardson S, Cullen PJ, Elpeleg O. A defect in the retromer 
accessory protein, SNX27, manifests by infantile myoclonic epilepsy and neurodegeneration. Neurogenetics. 2015;16(3):215-221.

84. Bitoun $M$, Stojkovic $T$, Prudhon B, Maurage CA, Latour P, Vermersch P, Guicheney P. A novel mutation in the dynamin 2 gene in a Charcot-Marie-Tooth type 2 patient: clinical and pathological findings. Neuromuscular disorders : NMD. 2008;18(4):334-338.

85. Zuchner $S$, Noureddine $M$, Kennerson M, Verhoeven K, Claeys K, De Jonghe P, Merory J, Oliveira SA, Speer MC, Stenger JE, Walizada G, Zhu D, Pericak-Vance MA, Nicholson G, Timmerman V, Vance JM. Mutations in the pleckstrin homology domain of dynamin 2 cause dominant intermediate Charcot-Marie-Tooth disease. Nature genetics. 2005;37(3):289-294.

86. Bohm J, Biancalana V, Dechene ET, Bitoun M, Pierson CR, Schaefer E, Karasoy H, Dempsey MA, Klein F, Dondaine N, Kretz C, Haumesser N, Poirson C, Toussaint A, Greenleaf RS, Barger MA, Mahoney LJ, Kang PB, Zanoteli E, Vissing J, Witting N, Echaniz-Laguna A, WallgrenPettersson C, Dowling J, Merlini L, Oldfors A, Bomme Ousager L, Melki J, Krause A, Jern C, Oliveira AS, Petit F, Jacquette A, Chaussenot A, Mowat D, Leheup B, Cristofano M, Poza Aldea JJ, Michel F, Furby A, Llona JE, Van Coster R, Bertini E, Urtizberea JA, Drouin-Garraud V, Beroud C, Prudhon B, Bedford M, Mathews K, Erby LA, Smith SA, Roggenbuck J, Crowe CA, Brennan Spitale A, Johal SC, Amato AA, Demmer LA, Jonas J, Darras BT, Bird TD, Laurino M, Welt SI, Trotter C, Guicheney P, Das S, Mandel JL, Beggs AH, Laporte J. Mutation spectrum in the large GTPase dynamin 2, and genotype-phenotype correlation in autosomal dominant centronuclear myopathy. Human mutation. 2012;33(6):949-959.

87. Dong J, Misselwitz R, Welfle H, Westermann P. Expression and purification of dynamin II domains and initial studies on structure and function. Protein Expr Purif. 2000;20(2):314323.

88. Ferguson SM, Raimondi A, Paradise $S$, Shen $H$, Mesaki K, Ferguson A, Destaing O, Ko G, Takasaki J, Cremona O, E OT, De Camilli P. Coordinated actions of actin and BAR proteins upstream of dynamin at endocytic clathrin-coated pits. Developmental cell. 2009;17(6):811822.

89. Chang HS, Won ES, Lee HY, Ham BJ, Kim YG, Lee MS. Association of ARRB1 polymorphisms with the risk of major depressive disorder and with treatment response to mirtazapine. Journal of psychopharmacology. 2015;29(5):615-622.

90. Jiang T, Yu JT, Wang YL, Wang HF, Zhang W, Hu N, Tan L, Sun L, Tan MS, Zhu XC, Tan L. The genetic variation of ARRB2 is associated with late-onset Alzheimer's disease in Han Chinese. Current Alzheimer research. 2014;11(4):408-412.

91. Nakamura M, Yamamoto S, Okada M, Ito S, Tano Y, Miyake Y. Novel mutations in the arrestin gene and associated clinical features in Japanese patients with Oguchi's disease. Ophthalmology. 2004;111(7):1410-1414.

92. Sippel KC, DeStefano JD, Berson EL, Dryja TP. Evaluation of the human arrestin gene in patients with retinitis pigmentosa and stationary night blindness. Investigative ophthalmology \& visual science. 1998;39(3):665-670. 


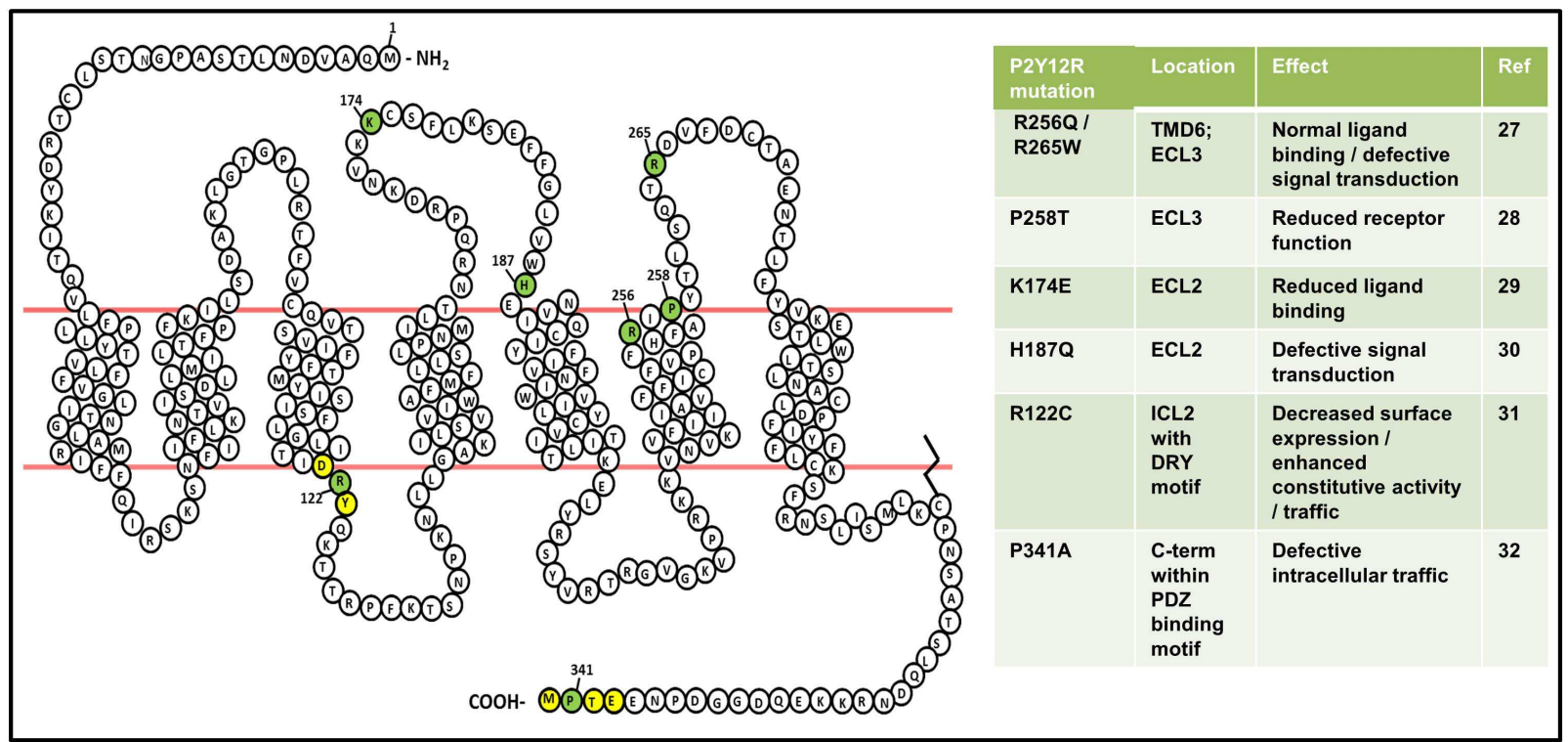

Figure 1: $\mathrm{P} 2 \mathrm{Y}_{12}$ Receptor Snake Plot

Sites of naturally-occurring variants found in patients with a bleeding history are highlighted in green. Key amino-acid regulatory motifs are highlighted in yellow (Specifically E/DRY motif and type 1 PDZ ligand). Details of these variants and their consequences upon receptor function outlined in adjacent table (ECL: extracellular loop, ICL: intracellular loop. TMD: transmembrane domain). 


\section{Highlights}

- Review focussing on rare, function-disrupting variants of $\mathrm{G}$ protein-coupled receptors (GPCRs).

- Specific emphasis on insights provided by single-nucleotide polymorphisms of platelet (GPCRs) including the P2Y12 receptor.

- Discussion on how such function-disrupting GPCR mutations provides an essential link in translating our understanding of receptor function in cell lines into relevant human biological systems. 